\title{
Electrochemical Preparation of Mg-Li-Al-Er Alloys by Co-reduction in Molten Chloride
}

\author{
Yi SUN, Milin ZHANG ${ }^{\dagger}$, Wei HAN, Mei LI, Yusheng YANG, Yongde YAN and Meng ZHANG \\ Key Laboratory of Superlight Materials and Surface Technology, Ministry of Education, College of Materials Science \\ and Chemical Engineering, Harbin Engineering University, Harbin 150001, China
}

[Manuscript received 11 December 2012, in revised form 29 March 2013]

(c) The Chinese Society for Metals and Springer-Verlag Berlin Heidelberg

\begin{abstract}
The electrochemical behavior of $\mathrm{Mg}, \mathrm{Li}, \mathrm{Al}$ and $\mathrm{Er}$ were investigated by electrochemical techniques in $\mathrm{LiCl}-$ $\mathrm{KCl}-\mathrm{MgCl}_{2}-\mathrm{AlCl}_{3}-\mathrm{ErCl}_{3}$ melts at $823 \mathrm{~K}$. The cyclic voltammetry and chronopotentiometry indicated that the co-reduction of $\mathrm{Mg}, \mathrm{Li}, \mathrm{Al}$ and $\mathrm{Er}$ occurs at current densities more negative than $-0.89 \mathrm{~A} \cdot \mathrm{cm}^{-2}$. $\operatorname{Er}(\mathrm{III})$ under-potential deposited on pre-reduced $\mathrm{Al}$ electrode formed Al-RE alloys. X-ray diffraction (XRD) results indicated that $\mathrm{Mg}_{17} \mathrm{Al}_{12}, \mathrm{Al}_{2} \mathrm{Er}_{2}, \mathrm{Al}_{2} \mathrm{Er}_{3}$ and $\mathrm{Al}_{4} \mathrm{Li}_{9}$ phases were prepared by galvanostatic electrolysis. ICP analyses of samples showed that lithium and aluminum contents of $\mathrm{Mg}$ - $\mathrm{Li}-\mathrm{Al}-\mathrm{Er}$ alloys could be controlled by concentration of $\mathrm{AlCl}_{3}$ and cathodic current density.
\end{abstract}

KEY WORDS: Mg-Li based alloys; Co-reduction; Rare earth; Molten salt electrolysis

\section{Introduction}

$\mathrm{Mg}$-Li based alloys are regarded as promising materials because of their low density and high strengthto-weight ratio ${ }^{[1-2]}$. However, the limited mechanical properties of $\mathrm{Mg}-\mathrm{Li}$ based alloys restrict their applications in microelectronics, automobile, and aerospace industries ${ }^{[3]}$. Therefore, researches have concentrated on the improvement of mechanical properties of $\mathrm{Mg}-\mathrm{Li}$ based alloys in recent years.

Addition of alloying elements such as $\mathrm{Al}, \mathrm{Zn}, \mathrm{Mn}$ and rare earth elements (RE) could enhance the mechanical properties of $\mathrm{Mg}$-Li based alloys. Kumar et $a l .{ }^{[4]}$ founded that the presence of $\mathrm{Al}, \mathrm{Sn}$ and $\mathrm{Zn}$ in $\mathrm{Mg}$-Li based alloys formed an unusual dual-phase microstructure, change in the lattice parameter and intriguing texture evolution after hot-rolling. Jiang et al. ${ }^{[5]}$ reduced the grain size of $\mathrm{Mg}-\mathrm{Li}-\mathrm{Al}$ cast alloys with the addition of Ti and B. Li et al. ${ }^{[6]}$ studied the effects of $\mathrm{Y}$ and $\mathrm{Sr}$ additions on as-cast microstructure of $\mathrm{Mg}-\mathrm{Li}-\mathrm{Al}$ alloys and found that the additions produce a strong grain refining effect in LA141 alloy.

† Corresponding author. Prof., Ph.D.; Tel: +86 45182533026 ; Fax: +86 45182533026 ;

E-mail: zhangmilin2011@163.com (Milin ZHANG)

DOI: $10.1007 / \mathrm{s} 40195-012-0253-7$
Wu et al. ${ }^{[7]}$ and $\mathrm{Li}$ et al. ${ }^{[8]}$ revealed that the addition of $\mathrm{Ce}$ and $\mathrm{Nd}$ could clearly improve the mechanical properties and obtained the $\mathrm{Mg}-\mathrm{Li}-\mathrm{Al}-\mathrm{Zn}-\mathrm{Ce}$ and $\mathrm{Mg}$-Li-Al-Nd alloys with excellent tensile strength and ductility, respectively.

In this work, Er and $\mathrm{Al}$ were chosen as the additive elements to prepare $\mathrm{Mg}-\mathrm{Li}-\mathrm{Al}-\mathrm{Er}$ alloys by electrochemical co-reduction of $\mathrm{Mg}, \mathrm{Li}, \mathrm{Al}$ and Er metallic ions from chloride melts on inert tungsten electrode. The co-reduction consists of a simultaneous reduction of two or more metallic ions on an inert electrode to form alloys. This process in aqueous media was described by Brenner ${ }^{[9]}$. Co-reduction of alloys on inert electrode exhibits advantages such as the controllable composition by electrolysis parameters and the reduction on inert electrode rather than active electrode which avoid the limitation of intermetallic diffusion ${ }^{[10]}$. Taxil et al. ${ }^{[11,12]}$ studied the co-reduction of $\mathrm{Nd}$ (III), $\mathrm{Ce}(\mathrm{III}), \mathrm{Sm}$ (III) with $\mathrm{Al}(\mathrm{III})$ ions on tungsten electrodes in $\mathrm{LiF}-\mathrm{CaF}_{2}$ medium and found that the co-reduction occurred at a potential range between the deposition of pure metals. Yan et al. ${ }^{[13]}$ investigated the co-reduction mechanism of $\mathrm{Al}(\mathrm{III})$ and $\mathrm{Nd}(\mathrm{III})$ ions in $\mathrm{LiCl}-\mathrm{KCl}$ melts and prepared Al-Li-Nd alloys at a more negative current density than limiting current density by galvanostatic electrolysis. Cohen ${ }^{[14]}$ studied the co-reduction of 
$\mathrm{Nb}(\mathrm{V})$ and $\mathrm{Ge}(\mathrm{V})$ ions in the KF-LiF eutectic solvent and obtained several intermetallic copounds of Nb-Ge alloys. In the previous works, the reduction of $\mathrm{Mg}$, $\mathrm{Li}$ and other ions in $\mathrm{LiCl}-\mathrm{KCl}$ melts was investigated and $\mathrm{Mg}-\mathrm{Li}-\mathrm{Zn}{ }^{[15]}, \mathrm{Mg}-\mathrm{Li}-\mathrm{Sm}^{[16]}$ and $\mathrm{Mg}-\mathrm{Li}{ }^{-S_{n}}{ }^{[17]}$ alloys on inert electrodes were prepared. However, the electrochemical co-reduction of $\mathrm{Mg}$-Li-Al-Er quaternary alloys has not been investigated yet.

In this study, electrochemical co-reduction of $\mathrm{Mg}$, $\mathrm{Li}, \mathrm{Al}$, and $\mathrm{Er}$ ions in $\mathrm{LiCl}-\mathrm{KCl}-\mathrm{MgCl}_{2}-\mathrm{AlCl}_{3}-\mathrm{ErCl}_{3}$ melts on inert tungsten electrodes is proposed for direct preparation of $\mathrm{Mg}$-Li-Al-Er quaternary alloys at $823 \mathrm{~K}$. The electrochemical behavior of $\mathrm{Mg}(\mathrm{II}), \mathrm{Li}(\mathrm{I})$, $\mathrm{Al}(\mathrm{III})$, and $\mathrm{Er}(\mathrm{III})$ were investigated employing electrochemical techniques.

\section{Experimental}

\subsection{Preparation and purification of the melts}

The $\mathrm{LiCl}$ and $\mathrm{KCl}$ used in experiments were dried under vacuum for more than $72 \mathrm{~h}$ at $573 \mathrm{~K}$ and $873 \mathrm{~K}$ to remove excess water. And then the chloride mixture ( $\mathrm{LiCl}: \mathrm{KCl}=50: 50$ (in wt.\%), analytical grade) was melted in an alumina crucible placed in a quartz cell inside an electric furnace. The temperature of melts was measured with a nickel-chromium thermocouple sheathed by an alumina tube. Before the electrolysis process, metal ion impurities were removed by pre-electrolysis for $4 \mathrm{~h}$ at $-2.20 \mathrm{~V}$ (vs. $\mathrm{Ag} / \mathrm{AgCl}$ ). $\mathrm{Mg}(\mathrm{III}), \mathrm{Al}(\mathrm{III})$ and $\mathrm{Er}(\mathrm{III})$ ions were introduced into the bath in the form of dehydrated $\mathrm{MgCl}_{2}, \mathrm{AlCl}_{3}$ and $\mathrm{ErCl}_{3}$ powder (analytical grade). All experiments were performed under an argon atmosphere

\subsection{Electrochemical apparatus and electrodes}

All electrochemical measurements were carried out using an Autolab electrochemical workstation (Metrohm Co., Ltd.) with the Nova 1.6 software package. The working electrode was tungsten (99.99\% purity) wire with a diameter of $1 \mathrm{~mm}$, which was polished thoroughly using $\mathrm{SiC}$ paper, and then cleaned in an ultrasonic ethanol bath. A spectrally pure graphite rod with diameter of $6 \mathrm{~mm}$ was used as the counter electrode. The reference electrode consisted of a silver wire with diameter of $1 \mathrm{~mm}$ and a quartz tube containing a solution of $1 \mathrm{wt} . \% \mathrm{AgCl}$ in $\mathrm{LiCl}-\mathrm{KCl}$ melts. All potentials were referred to the $\mathrm{Ag} / \mathrm{AgCl}$ couple. The active electrode surface area was determined after each experiment by measuring the immersion depth of electrode in the molten salts.

\subsection{Auxiliary techniques}

After the electrolysis, the Mg-Li-Al-Er alloys samples were washed by hexane $(99.8 \%$ purity) to remove salts adhered to the surface. The contents
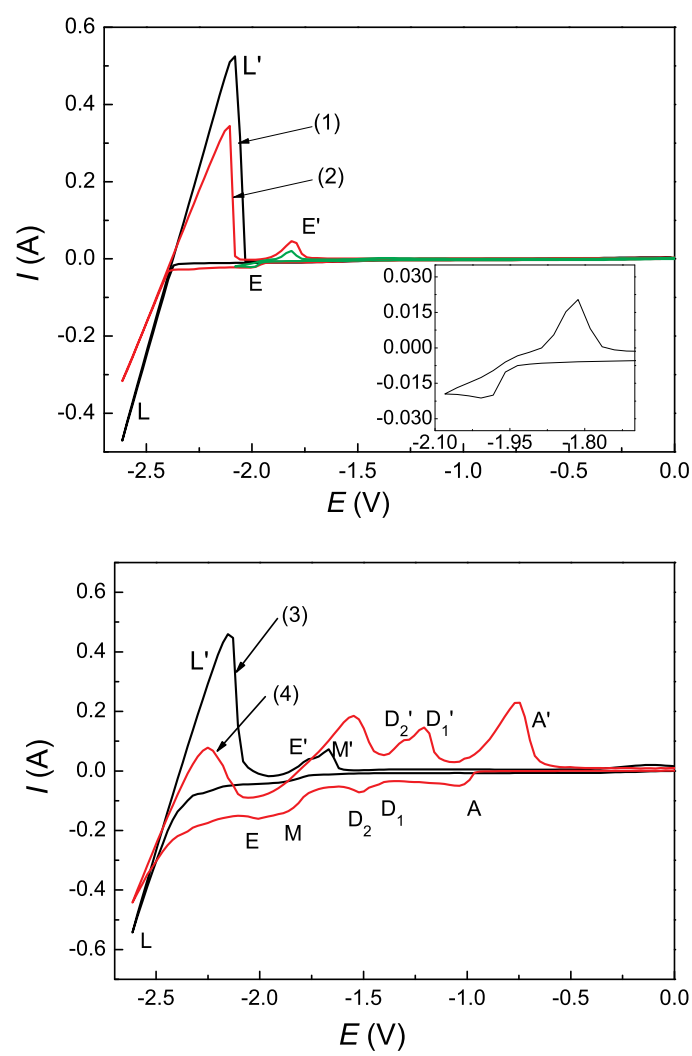

Fig. 1 Typical cyclic voltammograms of the LiCl-KCl$\mathrm{ErCl}_{3}$ melts containing different concentrations of $\mathrm{MgCl}_{2}$ and $\mathrm{AlCl}_{3}$ on tungsten electrodes with area of $0.314 \mathrm{~cm}^{2}$ at $823 \mathrm{~K}$ with the scan rate of $0.1 \mathrm{~V} \cdot \mathrm{s}^{-1}$ : (1) LiCl-KCl; (2) LiCl-KCl-1 wt. $\% \mathrm{ErCl}_{3} ;$ (3) LiCl-KCl-1 wt.\% $\mathrm{MgCl}_{2}-(1$ wt. $\%$ $\mathrm{ErCl}_{3} ;$ (4) LiCl-KCl-1 wt. $\% \mathrm{MgCl}_{2}-2$ wt. $\% \mathrm{AlCl}_{3}-$ 1 wt. $\% \mathrm{ErCl}_{3}$

of the Mg-Al-Li-Er alloys were analyzed by inductively coupled plasma atomic emission spectrometer (ICP-AES, Thermo Elemental, IRIS Intrepid II XSP). The phases of samples were analyzed by X-ray diffraction (XRD) (Multi Flex TTR III; Rigaku Industrial Corp. Ltd.) using $\mathrm{Cu} K_{\alpha}$ radiation at $40 \mathrm{kV}$ and $150 \mathrm{~mA}$. The microstructure and micro-zone chemical analysis were measured by SEM and EDS (JSM6480A, JEOL Co., Ltd.).

\section{Results and Discussion}

\section{$3.1 \mathrm{Cyclic}$ voltammetry of $\mathrm{LiCl}-\mathrm{KCl}-\mathrm{MgCl}_{2}-\mathrm{AlCl}_{3}-$ $\mathrm{ErCl}_{3}$ system}

The cyclic voltammograms were carried out in $\mathrm{LiCl}-\mathrm{KCl}$ melts with different concentrations of $\mathrm{ErCl}_{3}$, $\mathrm{AlCl}_{3}$ and $\mathrm{MgCl}_{2}$ on tungsten electrode (the area of the electrode, $S=0.314 \mathrm{~cm}^{2}$ at $823 \mathrm{~K}$, the results are shown in Fig. 1. Curve (1) corresponds to a cyclic voltammogram of the $\mathrm{LiCl}-\mathrm{KCl}$ melts without $\mathrm{AlCl}_{3}$, $\mathrm{MgCl}_{2}$, and $\mathrm{ErCl}_{3}$. A sharp increase (L) in cathodic current from approximately $-2.35 \mathrm{~V}$ (vs. $\mathrm{Ag} / \mathrm{AgCl}$ ) is observed which can be ascribed to the deposition of 
Li since no alloys or intermetallic compounds exist for the $\mathrm{W}-\mathrm{Li}^{[18]}$ binary system at $823 \mathrm{~K}$. In the reverse scan, an anodic peak $\mathrm{L}^{\prime}$ corresponding to the dissolution of $\mathrm{Li}$ is observed. After adding of $1 \mathrm{wt} . \% \mathrm{ErCl}_{3}$ in this molten salts system, another cathodic peak was detected, as shown in curve (2). The peaks $\mathrm{E}$ and $\mathrm{E}^{\prime}$ at $-1.99 \mathrm{~V}$ and $-1.82 \mathrm{~V}$ (vs. $\mathrm{Ag} / \mathrm{AgCl}$ ) are associated with the reduction and oxidation of Er ions on the tungsten cathode. The positions of these cathodic and anodic peaks are in agreement with those reported by Castrillejo et al. ${ }^{[19]}$ and Cao et al. ${ }^{[20]}$ in LiCl$\mathrm{KCl}$ melts. In Fig. 1, curve (3) represents the cyclic voltammogram of $\mathrm{LiCl}-\mathrm{KCl}-\mathrm{ErCl}_{3}-\mathrm{MgCl}_{2}$ melts. Another current peak observed at approximately -1.86 $\mathrm{V}$ is attributed to the reduction of $\mathrm{Mg}(\mathrm{II})$. Peak $\mathrm{M}^{\prime}$ in the positive-moving scan corresponds to the oxidation of $\mathrm{Mg}$. Curve (4) exhibits the voltammogram with addition of $\mathrm{MgCl}_{2}, \mathrm{AlCl}_{3}$, and $\mathrm{ErCl}_{3}$ in $\mathrm{LiCl}-\mathrm{KCl}$ melts, the other three pairs of cathodic/anodic current peaks are observed. Peaks $\mathrm{A} / \mathrm{A}^{\prime}$ corresponds to reduction/oxidation of $\mathrm{Al}$ ions on the tungsten cathode. Peaks $\mathrm{D}_{1}$ and $\mathrm{D}_{2}$ observed from approximately $-1.46 \mathrm{~V}$ and $1.51 \mathrm{~V}$. Since these potentials value are more positive than the potential of Er and Mg metal deposition, and there was no peak of $\mathrm{Mg}-\mathrm{Al}$ alloys observed in this area in $\mathrm{LiCl}-\mathrm{KCl}-\mathrm{MgCl}_{2}-\mathrm{AlCl}_{3}$ melt ${ }^{[21]}$, these cathodic peaks are thought to be caused by the formation of Al-Er alloys. Peaks $\mathrm{D}_{1}^{\prime}$ and $\mathrm{D}_{2}{ }^{\prime}$ correspond to Er dissolution from the alloys. After the addition of $\mathrm{AlCl}_{3}$, the reduction of $\mathrm{Mg}$ (II) ions at approximately $-1.84 \mathrm{~V}$, positive than the one of $\mathrm{Mg}$ metal deposition before the addition. The potential shift is due to a lowering of activity of the deposited metal $(\mathrm{Mg})$ in the pre-deposited $\mathrm{Al}$ and Al-Er alloys on tungsten electrode. And the potential of Li metal deposition after the addition $\mathrm{MgCl}_{2}$ and $\mathrm{AlCl}_{3}$ is more positive than the one Li metal deposition before addition, too.

\subsection{Square wave voltammetry of $\mathrm{LiCl}-\mathrm{KCl}-\mathrm{MgCl}_{2}$ - $\mathrm{AlCl}_{3}-\mathrm{ErCl}_{3}$ system}

The square wave voltammogram (SWV) is an analytical technique to determine the electron transfer number $(n)$ in an electrode process. The width of the half-peak, $W_{1 / 2}$, depends on $n$ and on the temperature, $T$, as follows ${ }^{[22]}$ :

$$
W_{1 / 2}=3.52 \frac{R T}{n F}
$$

where $R$ is the molar gas constant, $F$ is Faraday constant.

The number of electrons involved in the electrochemical reaction $\operatorname{Er}(\mathrm{III}) / \mathrm{Er}$ was also determined by square wave voltammetry. In Fig. 2, curve (1) displays a typical square wave voltammogram of $\operatorname{Er}(\mathrm{III})$ ions in $\mathrm{LiCl}-\mathrm{KCl}$ salts. A single peak at $-1.95 \mathrm{~V}$ (vs. $\mathrm{Ag} / \mathrm{AgCl}$ ) is obtained, which is bell-shaped and having an asymmetrical Gaussian shape. By using

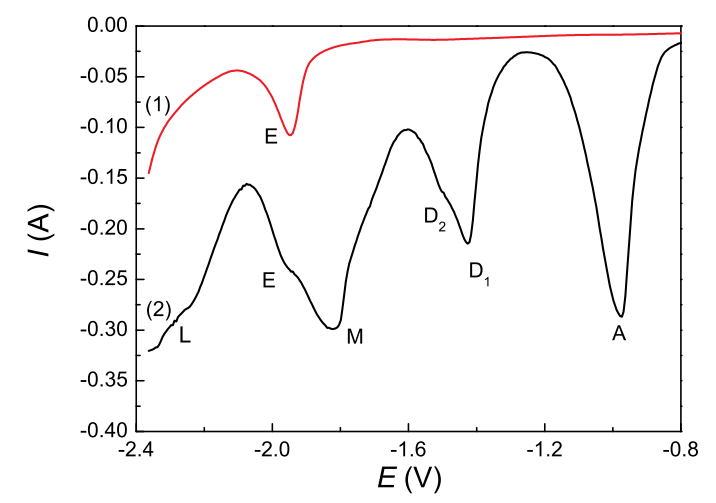

Fig. 2 Square wave voltammograms on tungsten electrode at $823 \mathrm{~K}$ in the $\mathrm{LiCl}-\mathrm{KCl}-\mathrm{ErCl}_{3}$ (curve (1)) and $\mathrm{LiCl}-\mathrm{KCl}-\mathrm{MgCl}_{2}-\mathrm{AlCl}_{3}-\mathrm{ErCl}_{3}$ (curve (2)) melts (frequency is $25 \mathrm{~Hz}$ )

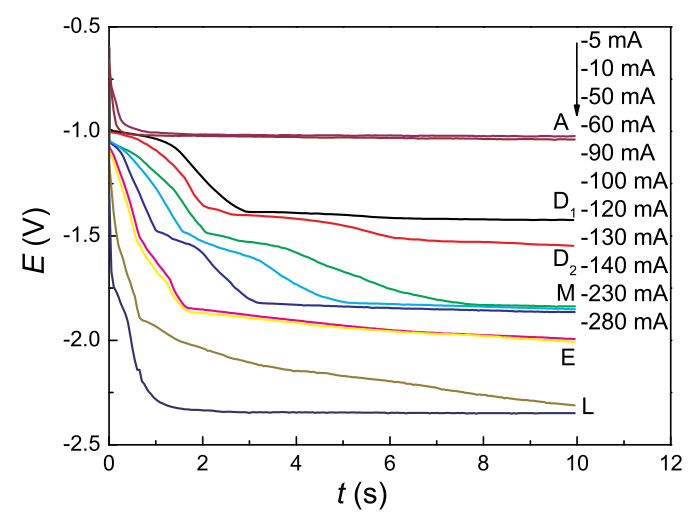

Fig. 3 Chronopotentiograms obtained at different current intensities on tungsten electrodes in the LiClKCl-1 wt. $\% \mathrm{ErCl}_{3}-1$ wt. $\% \mathrm{AlCl}_{3}-\mathrm{MgCl}_{2}$ melts at $823 \mathrm{~K}$

Eq. (1), the $n$-value was obtained to be 3.07 , which indicate three electrons were transferred. This value is in agreement with that reported by Castrillejo ${ }^{[19]}$. Curve (2) presents the SWV in $\mathrm{LiCl}-\mathrm{KCl}-\mathrm{MgCl}_{2}$ $\mathrm{AlCl}_{3}-\mathrm{ErCl}_{3}$ melts. Peaks $\mathrm{A}$ and $\mathrm{M}$ at $-0.98 \mathrm{~V}$ and $-1.82 \mathrm{~V}$ correspond to the formation of $\mathrm{Al}$ and $\mathrm{Mg}$ metal on the tungsten electrodes, respectively. The peaks $\mathrm{D}_{1}$ and $\mathrm{D}_{2}$ between $\mathrm{A}$ and $\mathrm{M}$ are identified as the formation of two phases of Al-Er alloys. Peak L is the reduction of $\mathrm{Li}$. The results of square wave voltammogram coincide with those obtained from the cyclic voltammograms.

\subsection{Chronopotentiometry of $\mathrm{LiCl}-\mathrm{KCl}-\mathrm{MgCl}_{2}-\mathrm{AlCl}_{3}-$ $\mathrm{ErCl}_{3}$ system}

Chronopotentiometry was employed to further investigate the electrochemical formation of $\mathrm{Mg}$-Li-AlEr alloys via co-reduction of Mg, Li, Al, and Er. Fig. 3 presents the chronopotentiograms were measured in LiCl-KCl- $\mathrm{MgCl}_{2}-1$ wt. $\% \mathrm{AlCl}_{3}-1$ wt. $\% \mathrm{ErCl}_{3}$ melts at different current intensities. The first plateau at $-1.04 \mathrm{~V}$ marked by $\mathrm{A}$ at the cathodic current lower than $-10 \mathrm{~mA}$ is associated with the reduction of 
Table 1 Compositions of the Mg-Al-Li-Er alloys were obtained under different electrolysis conditions

\begin{tabular}{|c|c|c|c|c|c|c|c|c|}
\hline \multirow[t]{2}{*}{ Sample } & \multirow{2}{*}{$\begin{array}{l}\text { Current density } \\
\left(\mathrm{A} \cdot \mathrm{cm}^{-2}\right)\end{array}$} & \multicolumn{3}{|c|}{ Mass of $\mathrm{AlCl}_{3}, \mathrm{MgCl}_{2}$ and $\mathrm{ErCl}_{3}$ in melt $(\mathrm{g})$} & \multirow{2}{*}{$\begin{array}{c}\mathrm{Li} \\
\text { (wt.\%) }\end{array}$} & \multirow{2}{*}{$\begin{array}{c}\mathrm{Al} \\
\text { (wt.\%) }\end{array}$} & \multirow{2}{*}{$\begin{array}{c}\text { Er } \\
\text { (wt.\%) }\end{array}$} & \multirow{2}{*}{$\begin{array}{c}\mathrm{Mg} \\
\text { (wt.\%) }\end{array}$} \\
\hline & & $\mathrm{AlCl}_{3}$ & $\mathrm{MgCl}_{2}$ & $\mathrm{ErCl}_{3}$ & & & & \\
\hline No.1 & 9.38 & 12 & 6 & 1 & 18.43 & 17.35 & 25.33 & Bal. \\
\hline No. 2 & 9.38 & 8 & 6 & 1 & 2.35 & 11.42 & 23.39 & Bal. \\
\hline No.3 & 9.38 & 6 & 6 & 1 & 62.90 & 2.76 & 3.62 & Bal. \\
\hline No.4 & 7.81 & 6 & 6 & 1 & 31.55 & 1.67 & 3.35 & Bal. \\
\hline No.5 & 6.25 & 6 & 6 & 1 & 0.97 & 0.28 & 0.62 & Bal. \\
\hline
\end{tabular}

$\mathrm{Al}(\mathrm{III})$. The other two plateaus marked by $\mathrm{D}_{1}$ and $\mathrm{D}_{2}$ are observed at $-1.41 \mathrm{~V}$ and $-1.52 \mathrm{~V}$, corresponding to the formation of two Al-Er alloys. In the range of -90 to $-120 \mathrm{~mA}$, the reduction of $\mathrm{Mg}$ (II) at $-1.85 \mathrm{~V}$ is readily observed. At the potential of $-1.99 \mathrm{~V}$, the plateau $\mathrm{E}$ is observed associated with the reduction of $\operatorname{Er}(\mathrm{III}) / \operatorname{Er}(0)$. When the applied current is up to $-280 \mathrm{~mA}\left(-0.89 \mathrm{~mA} \cdot \mathrm{cm}^{-2}\right)$, the potential plateau of approximate $-2.35 \mathrm{~V}$ (plateau L) can be ascribed to the deposition of $\mathrm{Li}$ on tungsten electrodes. At this current intensity, the co-deposition of $\mathrm{Mg}, \mathrm{Al}, \mathrm{Li}$, and Er occurs. It is obvious that the potential ranges for deposition of $\mathrm{Mg}, \mathrm{Al}, \mathrm{Er}$ and $\mathrm{Li}$ are the same as those observed in the cyclic voltammograms in section 3.1.

\subsection{Galvanostatic electrolysis of $M g-L i-A l-E r$ alloys and characterization}

Cyclic voltammograms, square wave voltammograms and chronopotentiograms show that electrochemical co-reduction occurred when the potentials are negative than $-2.35 \mathrm{~V}$ or the cathodic current densities are negative than $-0.89 \mathrm{~A} \mathrm{~cm}^{-2}$. But the limiting current density is too small to deposit enough alloys in a short time for analysis such as SEM and XRD. So the galvanostatic electrolysis were carried out at more negative current densities in LiCl-KCl$\mathrm{ErCl}_{3}$ (45:45:1, in wt.\%) melts with different concentrations of $\mathrm{MgCl}_{2}$ and $\mathrm{AlCl}_{3}$, using a tungsten electrode at $823 \mathrm{~K}$ for $2 \mathrm{~h}$. In all galvanostatic electrolysis experiments, the potential value was more negative than $-2.35 \mathrm{~V}$, which was sufficiently negative to produce Mg-Al-Li-Er alloys.

ICP analyses of samples obtained by galvanostatic electrolysis are listed in Table 1. Under the same current density, the content of $\mathrm{Al}$ in $\mathrm{Mg}-\mathrm{Li}-\mathrm{Al}-\mathrm{Er}$ alloys increases with the $\mathrm{AlCl}_{3}$ concentration, contents of Er in samples clearly increases with increase of $\mathrm{Al}$. It could be assumed that the Er is easier to combine with $\mathrm{Al}$, and deposited on the electrodes. Under the same $\mathrm{AlCl}_{3}$ and $\mathrm{MgCl}_{2}$ concentration in LiCl-KCl$\mathrm{ErCl}_{3}$ melts, with increase of current intensity the contents of $\mathrm{Al}, \mathrm{Li}$ and $\mathrm{Er}$ in alloys increased.

Fig. 4 shows the XRD patterns of Mg-Al-LiEr samples obtained by galvanostatic electrolysis from the $\mathrm{LiCl}-\mathrm{KCl}-\mathrm{ErCl}_{3}-\mathrm{MgCl}_{2}$ (45:45:1:6, in wt.\%) melts containing different concentrations of $\mathrm{AlCl}_{3}$ for $2 \mathrm{~h}$, cathodic current density is $9.38 \mathrm{~A} \cdot \mathrm{cm}^{2}$. The

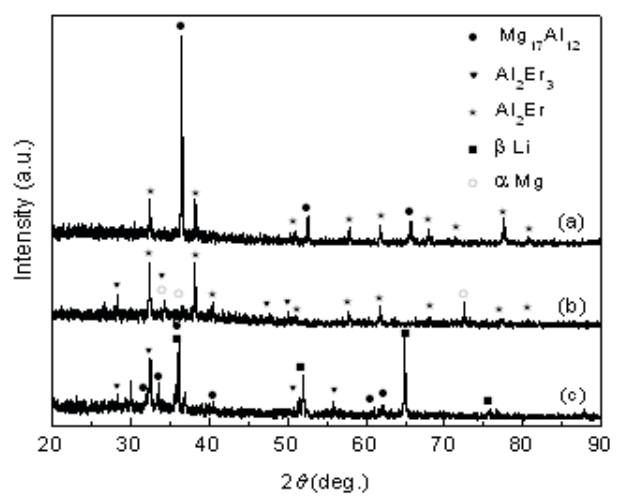

Fig. 4 XRD patterns of Mg-Al-Li-Er samples obtained by galvanostatic electrolysis with the current density $(j)$ is $-9.38 \mathrm{~A} \cdot \mathrm{cm}^{-2}$ from the LiCl-KCl$\mathrm{MgCl}_{2}-\mathrm{AlCl}_{3}-\mathrm{ErCl}_{3}$ melts with different compositions of $\mathrm{AlCl}_{3}$ for $2 \mathrm{~h}$ at $823 \mathrm{~K}$ : (a) 12 wt.\% $\mathrm{AlCl}_{3}$; (b) 8 wt. $\% \mathrm{AlCl}_{3}$; (c) 6 wt. $\% \mathrm{AlCl}_{3}$

observed peaks in Fig. 4(a) are identified as the $\mathrm{Mg}_{17} \mathrm{Al}_{12}$ and $\mathrm{Al}_{2}$ Er. With the decrease of $\mathrm{AlCl}_{3}$ concentration in $\mathrm{LiCl}-\mathrm{KCl}-\mathrm{ErCl}_{3}-\mathrm{MgCl}_{2}$ melts, the XRD pattern (Fig. 4(b)) indicate that the sample consist of $\mathrm{Al}_{2} \mathrm{Er}, \mathrm{Al}_{2} \mathrm{Er}_{3}$ and $\alpha$-Mg phases. When the concentrations of $\mathrm{AlCl}_{3}$ changed to 6 wt.\%, the sample was composed of $\mathrm{Mg}_{17} \mathrm{Al}_{12}, \mathrm{Al}_{2} \mathrm{Er}_{3}$ and $\beta$-Li due to the increase of li content in Mg-Al-Li-Er alloy (Fig. 4(c)). Based on the XRD, the Er mainly existed in the alloys in the form of $\mathrm{Al}_{2} \mathrm{Er}$ and $\mathrm{Al}_{2} \mathrm{Er}_{3}$ phases. The phase of $\mathrm{Mg}_{x} \mathrm{Er}$ was not observed since the electronegativity difference of Al-Er is more than that of $\mathrm{Mg}$-Er. The similar phenomena had been observed by Guo et $a l .{ }^{[23]}$ and Son et al. ${ }^{[24]}$ in the Sm-containing alloys.

From the SEM images shown in Fig. 5, the alloys exhibit a continuous or semi-continuous microstructure with some second phases distributed in the grain boundaries. To figure out the distribution of the elements of $\mathrm{Mg}, \mathrm{Al}$ and $\mathrm{Er}$ in the Mg-Al-Li-Er alloys, a SEM equipped with EDS quantitative analysis was applied, the results are presented in Fig. 6 and Fig. 7 . Fig. 6 shows that the element of $\mathrm{Mg}$ is distributed homogeneously throughout the Mg-Al-Li-Er alloy, while $\mathrm{Al}$ and Er are not uniform and dispersed mainly along the grain boundaries. The EDS results (Fig. 7) of points A and B taken from the grain boundary and grain in Fig. 5(b) indicate that $\mathrm{Er}$ and $\mathrm{Al}$ are dis- 


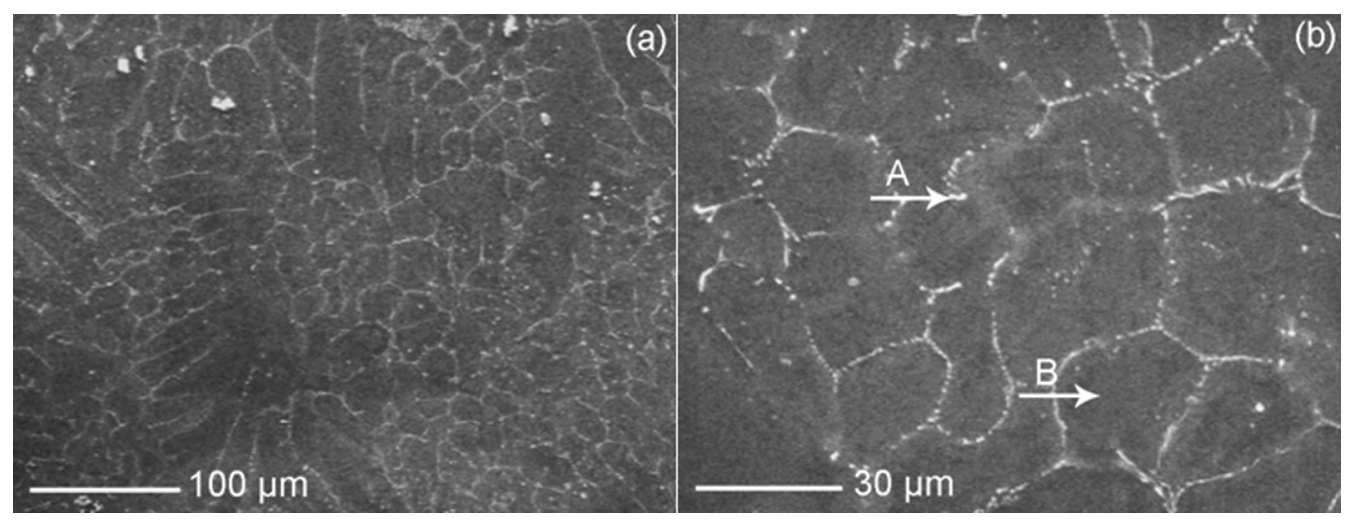

Fig. 5 SEM images of the Mg-Li-Al-Er alloys obtained by galvanostatic electrolysis $\left(j=-9.38 \mathrm{~A} \cdot \mathrm{cm}^{-2}\right)$ from LiCl-KCl-6 wt.\% $\mathrm{MgCl}_{2}-8$ wt.\% $\mathrm{AlCl}_{3}-1$ wt.\% $\mathrm{ErCl}_{3}$ melt for $2 \mathrm{~h}$ at $873 \mathrm{~K}$

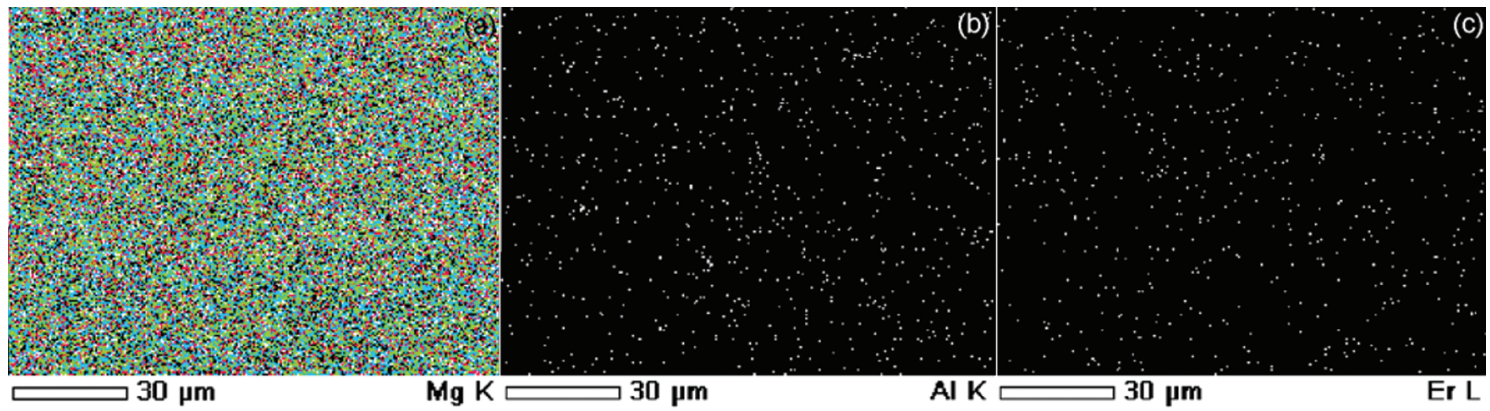

Fig. 6 EDS mapping analysis of the Mg-Li-Al-Er alloys according to Fig. 5(b)
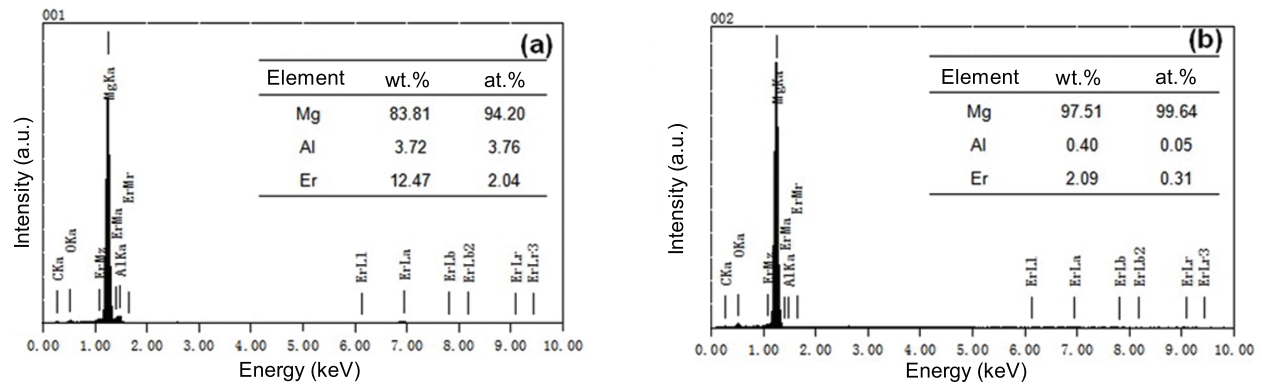

Fig. 7 Chemical constitutions of the point A (a) and point B (b) in Fig. 5 (b) obtained by EDS analysis

tributed more at the grain boundaries than inside the grains.

\section{Conclusions}

The electrochemical co-reduction behavior of $\mathrm{Mg}$, $\mathrm{Li}, \mathrm{Al}$ and $\mathrm{Er}$ on inert tungsten electrodes in $\mathrm{LiCl}-\mathrm{KCl}-\mathrm{MgCl}_{2}-\mathrm{AlCl}_{3}-\mathrm{ErCl}_{3}$ melts was studied at $823 \mathrm{~K}$. Electrochemical techniques showed that the co-reduction occurred when the current densities are more negative than $-0.89 \mathrm{~A} \cdot \mathrm{cm}^{-2}$.

Mg-Li-Al-Er alloys with $\mathrm{Mg}_{17} \mathrm{Al}_{12}, \mathrm{Al}_{2} \mathrm{Er}, \mathrm{Al}_{2} \mathrm{Er}_{3}$ and $\mathrm{Al}_{4} \mathrm{Li}_{9}$ phase were successfully prepared via galvanostatic electrolysis co-reduction of $\mathrm{Mg}, \mathrm{Li}, \mathrm{Al}$ and Er on inert tungsten electrodes in $\mathrm{LiCl}-\mathrm{KCl}-\mathrm{MgCl}_{2}-$ $\mathrm{AlCl}_{3}-\mathrm{ErCl}_{3}$ melts. The contents of $\mathrm{Mg}$, Li, $\mathrm{Al}$ and $\mathrm{Er}$ in $\mathrm{Mg}-\mathrm{Li}-\mathrm{Al}-\mathrm{Er}$ alloys can be controlled by $\mathrm{AlCl}_{3}$ concentrations and cathodic current density. An analysis of microstructures shows that the Er and $\mathrm{Al}$ elements are mainly distributed at the grain boundaries of the alloys.

\section{Acknowledgements}

The work was financially supported by High Technology Research and Development Program of China (No. 2011AA03A409), the National Natural Science Foundation of China (Nos. 21173060 and 21271054), the Major Research Plan of the National Natural Science Foundation of China (No. 91226201) and the Fundamental Research Funds for the Central Universities (No. HEUCF201310012). 


\section{REFERENCES}

[1] Z. Trojanová, Z. Drozd, P. Luká and F. Chmelík, Mater. Sci. Eng. A 410-411 (2005) 148.

[2] S.J. Wang, G.Q. Wu, R.H. Li, G.X. Luo and Z. Huang, Mater. Lett. 60 (2006) 1863.

[3] T.C. Chang, J.Y. Wang, C.L. Chu and S. Lee, Mater. Lett. 60 (2006) 3272.

[4] V. Kumar, Govind, R. Shekhar, R. Balasubramaniam and K. Balani, Mater. Sci. Eng. A 547 (2012) 38.

[5] B. Jiang, D. Qiu, M. X. Zhang, P.D. Ding and L. Gao, J. Alloys Compd. 492 (2010) 95.

[6] R.H. Li, F.S. Sheng, B. Jiang, H.M. Yin and T.T. Liu, Trans. Nonferrous Met. Soc. China 21 (2011) 778.

[7] L.B. Wu, C.L. Cui, R.Z. Wu, J.Q. Li, H.B. Zhan and M.L Zhang, Mater. Sci. Eng. A 528 (2011) 2174.

[8] M. Li, H. Hao, A.M. Zhang, Y.D. Song and X.G. Zhang, J. Rare Earths 30 (2012) 492.

[9] A. Brenner, Electrodeposition of Alloys, Academic Press, New York, 1963, p. 429.

[10] P. Taxil, P. Chamelot, L. Massot and C. Hamel, J. Miner Met. 39 (2003) 177.

[11] M. Gibilaro, L. Massot, P. Chamelot and P. Taxil, Electrochim. Acta 54 (2009) 5300.

[12] M. Gibilaro, L. Massot, P. Chamelot and P. Taxil, J.
Nucl. Mater. 382 (2008) 39.

[13] Y.D. Yan, Y.L. Xu, M.L. Zhang, Y. Xue, W. Han, Y. Huang, Q. Chen and Z.J. Zhang, J. Nucl. Mater. 433 (2013) 152.

[14] U. Cohen, J. Electrochem. Soc. 10 (1983) 1480.

[15] Y.D. Yan, M.L. Zhang, Y. Xue, W. Han, D. X. Cao and S. Q.Wei. Electrochim. Acta 54 (2009) 3387.

[16] W. Han, F.L. Wang, Y. Tian, M.L. Zhang and Y.D. Yan, Metall. Mater. Trans. B 42 (2012) 1376.

[17] P. Cao, M.L. Zhang, W. Han, Y.D. Yan and L.J. Chen, Acta Metall. Sin. (Engl. Lett.) 25 (2012) 265.

[18] J. Sangster and A.D Pelton, J. Phase Equilib. Diffus. 12 (1991) 203.

[19] Y. Castrillejo, M.R. Bermejo, E. Barrado and A.M. Martínez, Electrochim. Acta 51 (2006) 1941.

[20] P. Cao, M.L. Zhang, W. Han, Y.D. Yan, S.Q. Wei and T. Zheng, J. Rare Earths 29 (2011) 763.

[21] Y.D. Yan, M.L. Zhang, Y. Xue, W. Han, D.X. Cao and L.Y He, J. Appl. Electrochem. 39 (2009) 455.

[22] M.R. Bermejo, F. de la Rosa, E. Barrado and Y. Castrillejo, J. Electroanal. Chem. 603 (2007) 81.

[23] J. Guo, X.F. Bian, Q.G. Meng, Y. Zhao, X.L. Li, and S.J. Zhang, J. Alloys Compd. 431 (2007) 167.

[24] H.T. Son, J.S. Lee, D.G. Kim, K. Yoshimi and K. Maruyama, J. Alloys Compd. 473 (2009) 446. 